\title{
電解研削加工における材料除去特性に関する研究*
}

\author{
中島利勝 ${ }^{* *}$ 大橋一仁 ${ }^{* *}$ 上田晋一*** 山下 諭 $^{\dagger}$ 藤井直人***
}

Study on Material Removal Process in Electrolytic Grinding

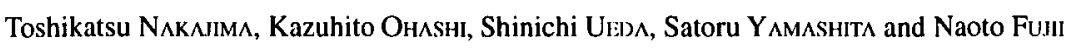

In this paper, the material removal mechanism in electrolytic grinding process is experimentally investigated by analyzing the stock removal due to electrolytic phenomenon and to grinding phenomenon in electrolytic grinding process, taking the inevitable accumulation phenomenon of interference depth of wheel into consideration. The material removal effect in electrolytic grinding is also discussed from the viewpoint of machining energy. Main conclusions obtained in this paper are as follows: (1) The electric current in electrolytic grinding process increases from beginning of wheel interference because of the momentary short circuit or electric discharge through generated chips at smaller concentration of electrolyte or applied voltage. Therefore all electric current isn't always consumed for the electrolytic effect. (2) There exists the critical electrolytic conditions from which the electrolytic effect in electrolytic grinding process intensifies. (3) The total consumed energy reduces with the increase of concentration of electrolyte or the applied voltage, but the effective energy rate for material removal decreases at about $7 \mathrm{~V}$ in applied voltage.

Key words: electrolytic grinding, stock removal, electrolytic effect, grinding effect, electric current, concentration of electrolyte, critical electrolytic conditions, effective energy rate

1. 緒言

電気化学的溶解作用と機械的研削作用の重畳によって材料除 去が進行する電解研削は, 電解作用によって砥石への負荷が軽 減されるため主に難削材に対して有効な加工法の一つである. その複雑な材料除去機構を解明寸るためには電解研削現象にお ける各除去作用の割合を求めることが必要であり，これまでに 工作物速度が極めて小さく砥石通過直後の過剩な電解溶出に よってオーバカット現象を伴う加工条件においては,小野らに よって材料除去量に占める電解作用の割合が求められている 1. 21. 一方, 過剩な電解溶出が発生せず，加工精度および能率 に優れる高い工作物速度の条件については長谷川らによって検 討されているが, 主に研削抵抗の減少効果を対象としている3!

そこで本研究では, 過剩な電解溶出が発生しない工作物速度 で電解研削する場合の材料除去機構をより精確に把握するた め, 研削過程において必然的に生じる砥石のかつぎ現象をを考 慮に加之，円筒プランジ電解研削する場合の電解作用および研 削作用が材料除去量に占める割合を検討し,電解液濃度および 印加電圧が電解研削の材料除去特性に及ぼす影響を明らかにす る.さらに, 電解研削による材料除去効果を加工動力の観点か ら明らかにする。

\section{2. 電解研削方法および条件}

図1に円筒研削盤を用いた電解研削装置の概略を示す. 奏験 は円筒プランジ方式で行った。研削砥石には導電性を有するメ タルボンドダイヤモンド砥石を用い,工作物とともに取付け穴 の内面および側面の絶縁材によって供給電流の不要な部分への リークを防止した. なお，砥石表面には各実験前に立形ロータ リドレッサを用いて所定のッルーイングならびにドレッシング を施した5). 電源には直流電源を使用し，陽極である工作物に

\footnotetext{
* 原稿受付 平成 12 年 3 月 2 日

** 正 会 員 岡山大学工学部 (岡山市津島中 3-1-1)

*** 学生会貝 岡山大学大学院 (岡山市津島中 3-1-1)

†学生会貝 岡山大学大学院 (現, (株) ノーリッ 明石市二見町 南二見 5)
}

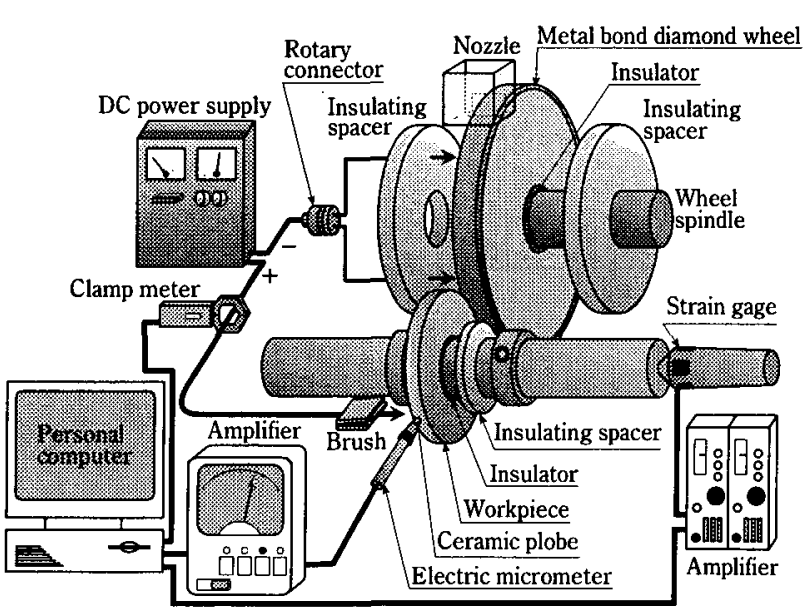

Fig. 1 Experimental apparatus for electrolytic grinding

はブラシを,陰極である砥石にはロータリコネクタを介して所 定の電压を印加した，電解液には硝酸カリウム $\left(\mathrm{KNO}_{3}\right)$ の水溶 液を用い, 研削点に確実に供給されるように巻付けノズル6を 使用した。主な加工条件は以下のとおりである。

研削砥石:SD170N125M-3.0

工 作 物: SK3 $(\phi 100 \times 10 \mathrm{~mm}$, 非熱処理 $)$

硑石周速度 : $\dot{V}_{\mathrm{s}}=1979 \mathrm{~m} / \mathrm{min}$

速 度 比: $K_{v}=V_{\mathrm{w}} / V_{\mathrm{s}}=0.00943\left(V_{\mathrm{w}}:\right.$ 工作物周速度)

設定砥石切込み量 : $\Delta=0.5 \mu \mathrm{m} / \mathrm{rev}$ of workpiece

研削系剛性 ${ }^{4)}: k_{\text {sy }}=11.14 \mathrm{~N} / \mu \mathrm{m}$

電 解 液: 硝酸カリウム $\left(\mathrm{KNO}_{3}\right)$ 水溶液

電解液濃度: $C_{\mathrm{e}}=2 \sim 10 \% \mathrm{wt}$.

印加電圧: $E=5 \sim 15 \mathrm{~V}(\mathrm{DC})$

研削抵抗は工作物支持センタに貼り付けたひずみゲージによ ク，工作物の寸法生成量は電気マイクロメータにより，また直 流電源から供給される電流はクランプメータにより検出し，そ れぞれパーソナルコンピュータに出力した。加工面の表面粗さ は触針式粗さ計で，さらに光沢度計を用いて加工面の光沢度を 測定した。 


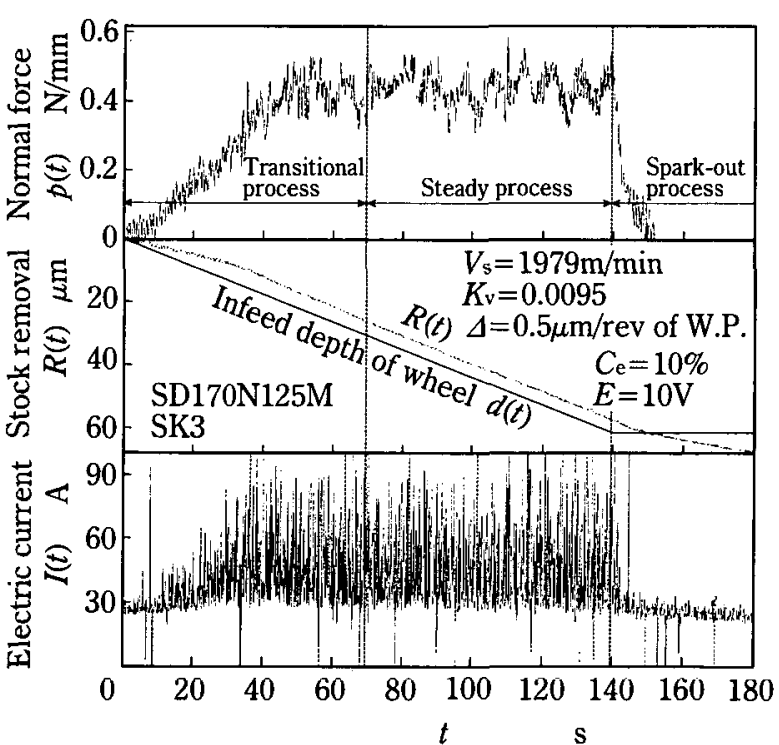

Fig. 2 Variations of normal force, stock removal and electric current in plunge electrolytic grinding process

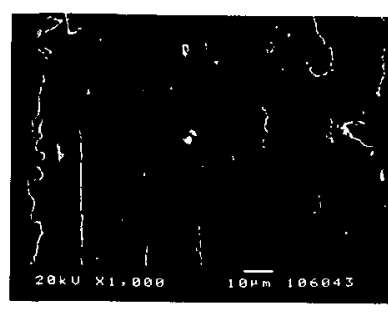

$C_{\mathrm{e}}=6 \%, E=5 \mathrm{~V}$

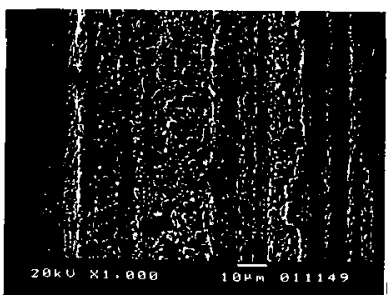

$C \mathrm{e}=6 \%, E=12.5 \mathrm{~V}$

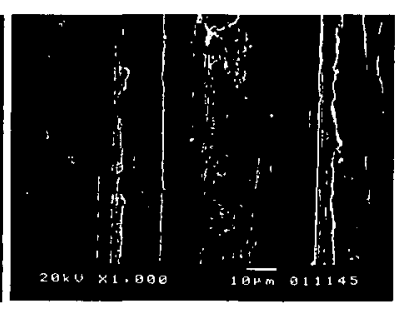

$C_{\mathrm{e}}=6 \%, E=7.5 \mathrm{~V}$

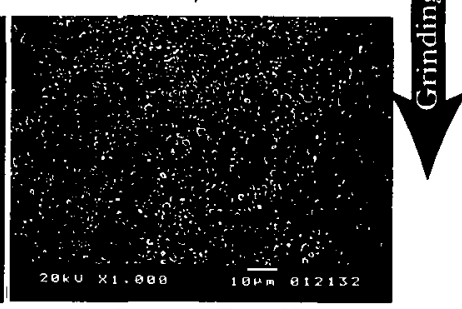

$C_{e}=10 \%, E=15 \mathrm{~V}$
Fig. 3 SEM photographs of electrolytic ground surface

\section{3. 円筒プランジ電解研削過程}

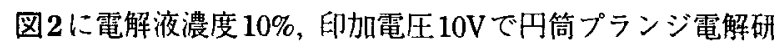
削する場合の 1 つの研削サイクルにおける砥石台移動量 $d(t)$, 研削背分力 $p(t)$, 寸法生成量 $R(t)$ および砥石と工作物間の電流 $I(t)$ の変化過程を示す．研削背分力および寸法生成量ともに過 渡, 定常, スパークアウト研削過程において, 電解を伴わない 通常のプランジ研削加工の場合4!とほぼ同様に変化するが, 電 解作用を伴うため砥石と工作物の干涉開始と同時に寸法が生成 され始める。砥石と工作物間の電流は砥石の干涉開始時点にお いて約 25Aであるが，研削の進行とともに変動を伴いながら 徐々に増大し，定常研削状態に達するとかなり広い領域にわ たって大きく変動するようになる。ここで砥石台の切込みを停 止しスパークアウト研削過程に移行すると,電流の变動は急速 に減少し、電解の進行によって砥石と工作物との間隙が徐々に 広がるため電流は徐々に減少するものの電流の供給が続くた め,電解作用によって寸法生成量は徐々に増加し砥石の切込み 量を上回る. 以上のことから，本報では主に定常研削状態にお ける材料除去特性について検討する.

\section{4. 電解研削面性状}

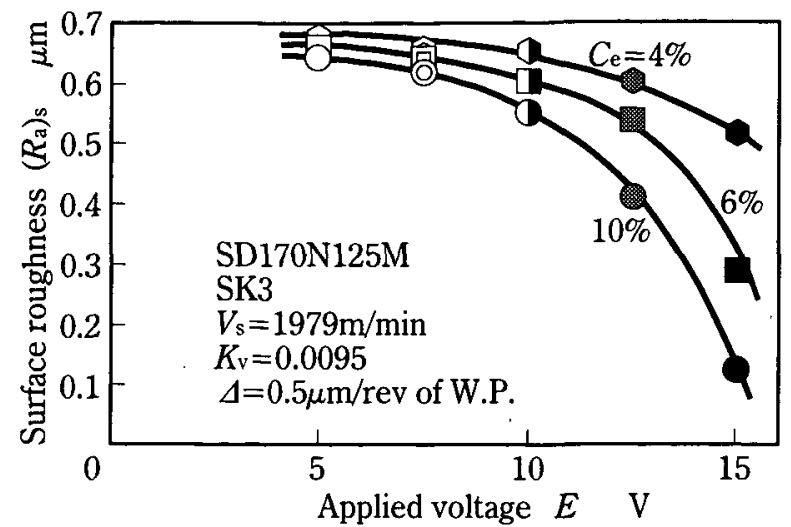

Fig. 4 Effects of concentration of electrolyte and applied voltage on surface roughness

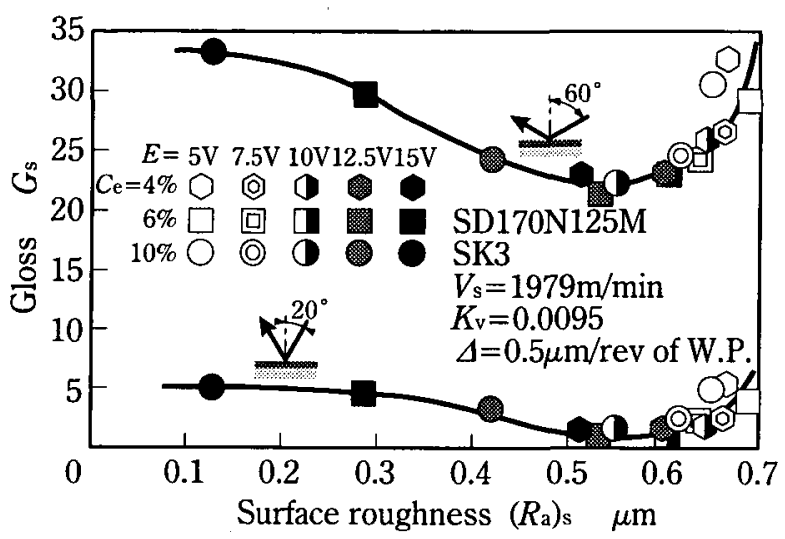

Fig. 5 Relationships between surface roughness and gross on electrolytic ground surface

図3に6\%の電解液で異なる印加電圧で電解研削した場合な らびに電解液濃度 $\mathrm{Ce}=10 \%$, 印加電圧 $E=15 \mathrm{~V}$ で電解研削した 定常研削状態における電解研削面をSEMで観察した結果を示 す. $C_{\mathrm{e}}=6 \%$ では印加電圧が小さい場合は通常の研削面とほと んど同様であるが, 印加電圧が大きくなり，電解作用が大きく なるに従って電解によって材料が溶出した痕跡が明瞭に現れ， 砥粒の干涉による条痕が徐々に消滅する。さらに大きな電解作 用が現れる $C_{\mathrm{e}}=10 \%, E=15 \mathrm{~V}$ の加工面には砥粒の干涉痕が確認 されず，加工面全体が電解によって生成された面になる。これ は，砥粒切れ刃が工作物表面に干涉した後に結合剤表面との強 い電解作用によって電解溶出がなさ礼るためであるい。

図 4 は，電解液濃度 $C_{\mathrm{e}}$ ならびに印加電生 $E$ が定常研削状態 における電解研削面の粗さ $\left(R_{\mathrm{a}}\right)_{\mathrm{s}}$ に及ほす影響を示すものであ る. 電解研削面粗さは電解液濃度が高くなるに従って，また大 きい印加電压で加工するほど改善され，特に比較的大きい印加 電圧の場合にその傾向が顕著になる.このような電解条件によ る表面粗さの変化は，図了に示した電解研削面の観察結果加ら わかるように電解液濃度ならびに印加電圧が大きくなるほど電 解作用により研削条痕の凸部が顕著に除去されるためである。

一般に, 電解研削面は図3に示したように陽極酸化膜に覆わ れ，通常の研削面のような金属光沢は得られない，そこで，図 4 に示した各定常電解研削面の光沢度 $G \mathrm{~s}$ と表面粗さ $R_{\mathrm{a}}$ との関 係を図 5 に示す，なお，光沢度は JIS Z 8741 71 を基に研削方向 に沿って加工面に対して $20^{\circ}$ および $60^{\circ}$ の方向から光を照射し た值である.光沢度は一般に仕上面粗さには現れない表面の極 めて微細な性状によって決定される。電解作用が強まり表面粗 さが約 $0.5 \mu \mathrm{m} R$ a まで減少するに従って，電解研削面の光沢度は 


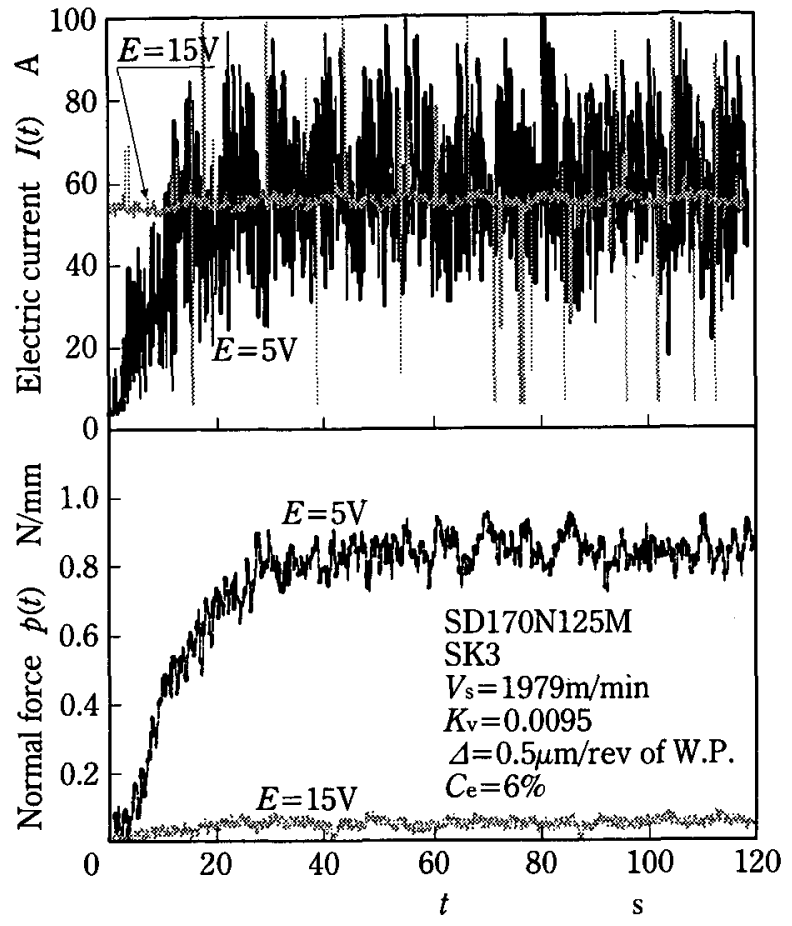

Fig. 6 Variations of electric current and normal force in electrolytic grinding process at $5 \mathrm{~V}$ and $15 \mathrm{~V}$ in applied voltage

徐々に減少するが,更に電解作用が強まり表面粗さが小さくな ると光沢度は逆に徐々に大きくなり，電解の効果が小さい約 $0.7 \mu \mathrm{m} R \mathrm{a}$ の電解研削面とほほ同様な光沢度になる．このような 表面粗さに対する光沢度の变化は, 図3に示したように電解液 濃度および印加電圧が小さく電解作用が比較的弱い場合に個々 の研削条痕の表面には細かい斑状の陽極酸化膜が生成される が,電解液濃度および印加電圧の大きい条件では研削条痕が確 認されず，陽極酸化膜の表面が細かい斑状から滑らかな表面に 変化するためである.以上から，図に示すプロット点の順序が 電解作用の強さを表徴すると考えら机，Ce=10\%，E=10V を境 に2つの異なる形態によって表面が創成されることがわかる.

\section{5. 材料除去特性の検討}

\section{1 電解研削過程における電解溶出電流}

図6は，6\%の電解液を用いて $5 \mathrm{~V}$ よび $15 \mathrm{~V}$ の電圧を印加さ せて円筒プランジ電解研削する場合の電源電流 $I(t)$ および研削 背分力 $p(t)$ の過渡から定常状態における变化過程である.印加 電圧が5Vの場合は，図2でも述べたように砥石と工作物の接 触開始から電流は急増し，激しい变動を伴いながら約 $55 \mathrm{~A} に$ 収束する。一方，印加電圧が $15 \mathrm{~V}$ の場合は砥石と工作物の接触 開始時点において電流はすでに55A程度であり，若干の変動を 伴って定常状態では印加電圧が5Vの場合とほぼ同様な值の電 流になる。電解研削に要する電流は，一般に電源から供給され る電流值として検出され評価さ机る。したがって, 図に示す 2 つの条件で電解研削する場合, 定常状態ではほは同等の電流で ありその做からはあたかも同様な電解効果が生じていると解 积される。しかし，図に示す研削背分力は定常研削状態におい て印加電圧が $15 \mathrm{~V}$ の場合のほほ $1 / 10 に$ に過ぎない.したがって, 計測された電源電流が同等でも加工条件によって電解効果が異 なることがわかる、

次に,この現象を解明するために，材料除去の観点から電解 効果を検討する.砥石と工作物の干涉点近傍では接触剛性など によるかつぎ現象 ${ }^{4}$ が存在するため、このかつぎ現象による電

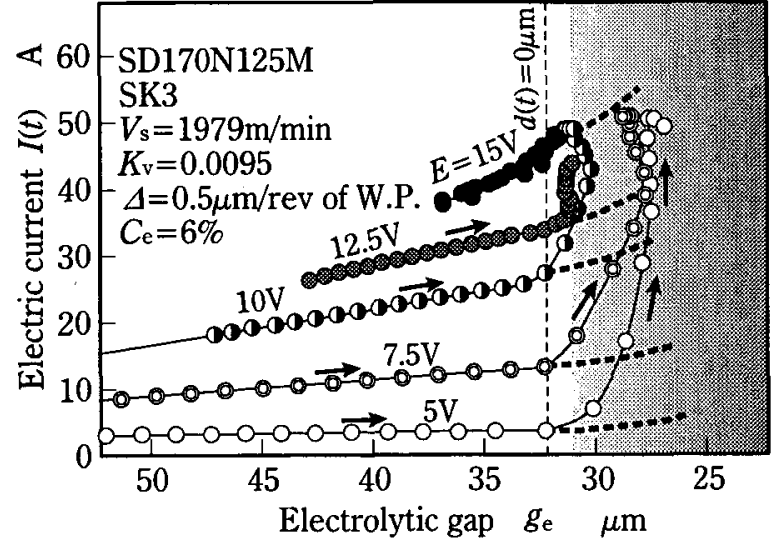

Fig. 7 Relationships between electrolytic gap and electric current in electrolytic grinding process

解作用への影響を考慮しなけ机ばならない。そこで, 砥石と工 作物が接触する前から砥石と工作物が接触し定常研削状態に移 行するまでの工作物表面と砥石の結合刘表面との間鿣 $g_{\mathrm{e}}$ に対す る電流 $I(t)$ の変化過程を図 7 に示す，なお，横軸である $g_{\mathrm{e}}$ は研

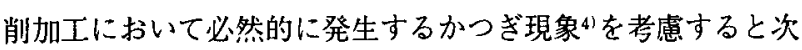
式で表すことができる。

$$
g_{\mathrm{e}}=\bar{h}_{\mathrm{r}}-\left\{d(t)-R(t)-d_{0}(t)-d_{1}(t)\right\}
$$

ここで, $\bar{h} \mathrm{r}$ は平均砥粒突出量, $d(t)$ は砥石と工作物との接触位 置からの砥石台移動量, $R(t)$ は寸法生成量, $d_{0}(t)$ は砥石摩耗量 ${ }^{4)}, d_{1}(t)$ は砥石軸および工作物支持部の弾性変位量41である. し たがって, 砥石が工作物に干渉するまでと干渉後の各過程にお いてgeは次式によって求められる。

$$
\begin{gathered}
g_{\mathrm{e}}=\bar{h}_{\mathrm{r}}-d(t) \quad(d(t) \leqq 0) \\
g_{\mathrm{e}}=\bar{h}_{\mathrm{r}}-\left\{d(t)-R(t)-d_{0}(t)-d 1(t)\right\}=\bar{h}_{\mathrm{r}}-d_{\mathrm{r}}(t) \quad(d(t)>0)
\end{gathered}
$$

ここで, $d_{\mathrm{r}}(t)$ は砥石と工作物の接触剛性ならびに表面粗さに起 因する切残し量4である。なお，ドレッシングした砥石表面に おいて砥粒の突出量は平均砥粒径の約 $1 / 3$ あるることが確認さ れたことから $\bar{h}_{\mathrm{r}}$ を $32.2 \mu \mathrm{m}$ とする．図のように，砥石が工作物 に干涉寸る $g_{\mathrm{e}}=32.2 \mu \mathrm{m}$ までは間隙 $g_{\mathrm{e}}$ の減少に従って電流は 徐々に増加し，その増加割合は印加電圧が高いほど大きい，し かし，砥石と工作物が接触し材料除去が始まると $g_{\mathrm{e}}$ の減少に 伴って電流は急激に大きくなり，定常研削状態では印加電圧に かかわらずほほ55Aに達する。このような傾向は印加電圧が小 さいはど顕著である。この結果を図6に示した電流の変動から 考虑すると, 印加電圧が小さい場合は電解作用が微弱であるた め，低粒切机刃によって生成さ机た切りくずが結合剤表面との 間隙を小さくすることによる放電現象"あるいは切りくずを介 した短絡が瞬時に発生していることが考えられる。一方，高い 印加電圧の場合は激しい電解作用によって短絡などの現象が生 じていないことが予測される。したがって，砥石と工作物が接 触した後の電源電流からは電解作用による材料除去量を求める ことは不可能である、そこで, 図了に示した加工面の観察結果 では表面に放電痕がほとんと観察されないことから,電流の供 給による材料除去効果は主に電解作用であるとし, 砥石が干渉 した後の電解溶出電流を特定する.

一般に，電解速度 $\dot{R}_{\mathrm{e}}$ と問隙 $g_{\mathrm{e}}$ との関係はファラディーの法 則に基づいて次式"で与えられる。

$$
\dot{R}_{\mathrm{e}}=\frac{\eta M \kappa(E-\Delta E)}{n F \gamma g_{\mathrm{e}}}
$$




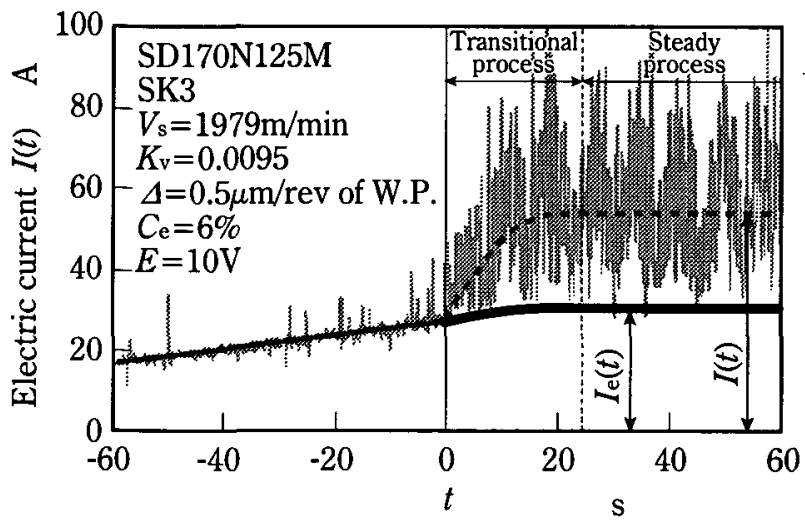

Fig. 8 Electrolytic current in electric current spent in electrolytic grinding process

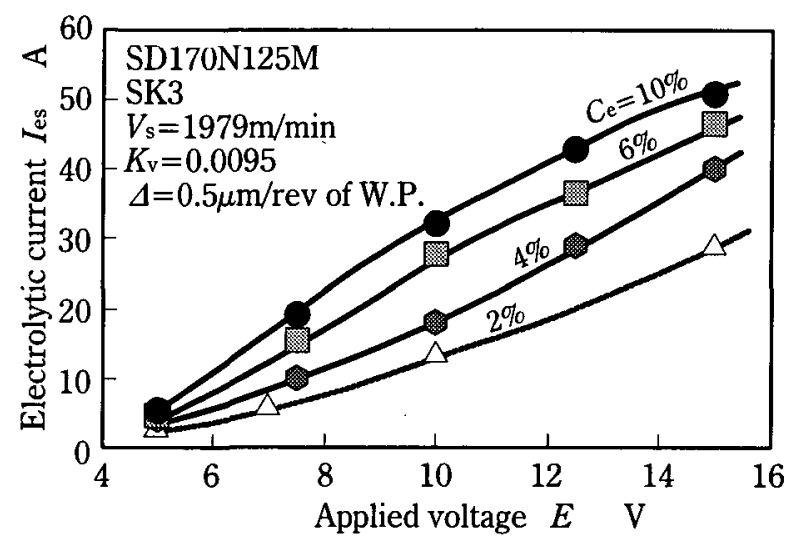

Fig. 9 Effects of concentration of electrolyte and applied voltage on electrolytic current

ここで, $M$ は原子量， $E$ は印加電圧， $\Delta E$ は各種要因による電 圧低下量 ${ }^{8)}, F$ はファラディー定数, $\eta$ は電解効率, $\kappa$ は電解液 の比電導度, $n$ は原子価である.

また,ファラディーの法則から電解速度 $\dot{R} \mathrm{e}$ と電解電流 $\mathrm{I}$ と の関係は次式で表される。

$$
\dot{R}_{\mathrm{e}}=\frac{\eta M I_{\mathrm{e}}}{n \gamma}
$$

したがって, 式 (4) と (5) から間隙 $g_{\mathrm{e}}$ と電解電流 $\mathrm{I}$ は次式の 反比例の関係を有する。

$$
I_{\mathrm{e}}=\frac{\kappa(E-\Delta E)}{F g_{\mathrm{e}}}
$$

砥石が工作物と接触するまでは電解作用のみによって材料除 去が推行するので, $g_{\mathrm{e}} \leqq 32.2 \mu \mathrm{m} に お け る g_{\mathrm{e}}$ と $I(t)$ との関係から 式(6)に基づいて砥石が接触した後の電解に要される電流の変 化を求めると図中の破線で表される。破線で示寸電解溶出電流 と電源電流を比較すれば, 印加電圧が15Vの場合は砥石と工作 物が干渉した後もほほ破線に沿って增加するものの，印加電圧 が小さい場合は砥石干涉後に電源電流は破線を外れ急激に大き くなる.この両者の差が切りくずを介した工作物と結合剤表面 との短絡などに起因する材料除去にはほとんど関与しない電流 であり，印加電圧が減少することに伴う電解作用の軽隇に伴っ てこの電流は增加する傾向にある.このことはこれまでに示し た加工表面の観察結果ならびに研削抵抗の変化過程からも襄付 けられる。

これまでに述べた工作物と結合郕表面の間榢と電解電流との 関係から, 電解研削過程における電解電流の変化を検討する. 図8は，電解液濃度 $6 \%$, 印加電圧 $10 \mathrm{~V}$ で電解研削する場合の

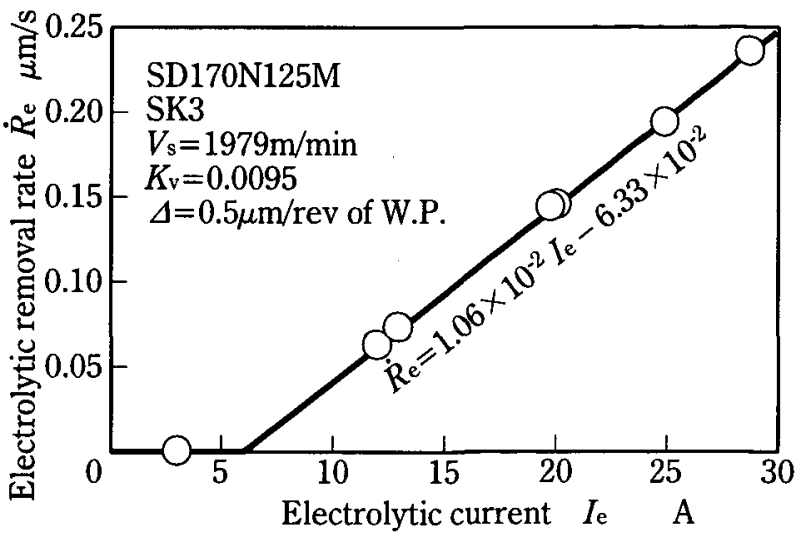

Fig. 10 Relationships between electrolytic current and electrolytic removal rate

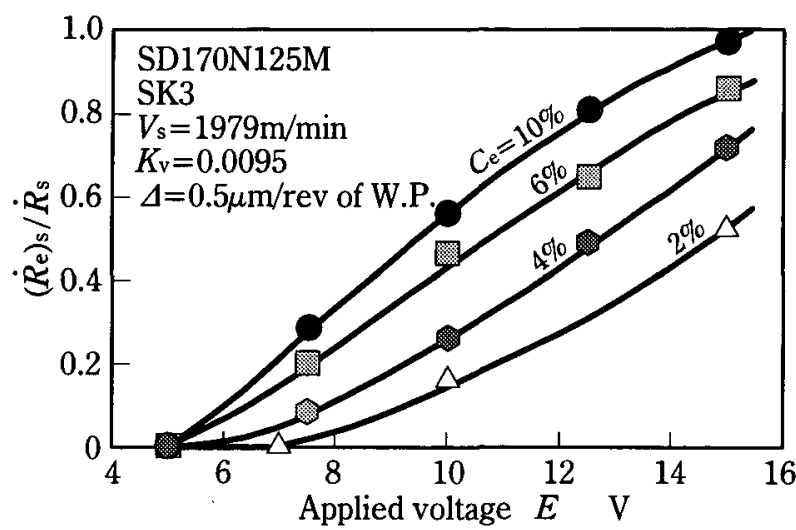

Fig. 11 Effects of concentration of electrolyte and applied voltage on electrolytic removal ratio

電流の変化過程を示すものである.電流 $I(t)$ は砥石が工作物表 面に近づくにつれて俆々に增加し，砥石の接触とともに変動を 伴いながら破線で示すように急激に大きくなり約50Aになると 定常状態になる。ここに図6の関係から得られる電解電流 $I_{\mathrm{e}}$ の 変化過程を表すと図中の奏線のようになり，砥石が工作物に接 触した以降もI $\mathrm{e}$ は緩やかに增加し，定常状態では $I(t)$ のおよそ 60\%までにしか達しない。

図 9 に定常研削状態における電解電流 $I_{\mathrm{es}}$ に及ばす印加電压 ならびに電解液濃度の影響を示す. 図のように, 印加電圧およ び電解液濃度が大きくなるに従ってI es は大きくなり，電解効 果が高くなる.しかし，印加電圧が小さい場合の電解電流は僅 かで, 図5に示した $C_{\mathrm{e}}=6 \%, E=5 \mathrm{~V}$ の場合は約 $50 \mathrm{~A} の$ 電流の内， 電解電流は僅か $3 \mathrm{~A}$ 程度にしか充なない。

\section{2 電解作用による材料除去効果}

次に,電解研削による材料除去過程における電解作用の效果 を検討する．そこでまず，砥石と工作物が接触していない状態 で求めた電解電流Ie と電解溶出速度 $\dot{R}$ との関係を図10に示す. 電流が的 $6 \mathrm{~A}$ までは電解作用がほとんど認められないが，それ より電流が大きくなると電解溶出速度は直線的に増大寸る。こ の関係と図 9 に示した電解電流を基に求めた電解溶出速度 $(\dot{R} \mathrm{e})_{\mathrm{s}}$ が定常研削状態における寸法生成速度 $\dot{R}_{\mathrm{s}} に$ 占める割合 $\left(\dot{R}_{\mathrm{e}}\right)_{\mathrm{s}} / \dot{R}_{\mathrm{s}}$ と電解条件との関係を図11に示す. $\left(\dot{R}_{\mathrm{e}}\right)_{\mathrm{s}} / \dot{R}_{\mathrm{s}}$ は，図9に示した 電解電流と同様に印加電圧ならびに電解液濃度に影響され, 最 も電解効果が高い $\mathrm{e}=10 \%, E=15 \mathrm{~V}$ の条件では除去される材料 のほとんどが電解によって除去される。一方， $E=5 \mathrm{~V}$ の場合は 電解による材料除去はほとんどなされず,印加電圧によって電 解効果が大きく異なることがわかる。また，電解液濃度が高い 
Electrolytic removal rate $\left(\dot{R}_{\mathrm{e}}\right)_{\mathrm{s}} \quad \mu \mathrm{m} / \mathrm{rev}$ of W.P.

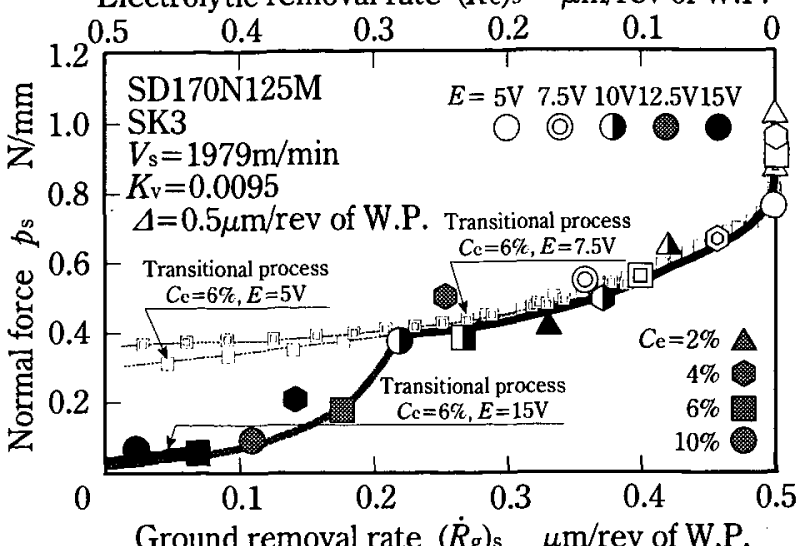

Fig. 12 Relationships between normal grinding force and ground removal rate or electrolytic one

ほど印加電圧による電解効果の変化は大きい。

以上の結果を基に，電解研削による材料除去性能を検討す る.図 12 は，定常研削状態における砥粒切机刃の干涉による 機械的な材料除去速度 $\left(\dot{R}_{\mathrm{g}}\right)_{\mathrm{s}}$ および電解溶出速度 $(\dot{R} \mathrm{e})_{\mathrm{s}}$ と定常研 削背分力 $p_{\mathrm{s}}$ との関係を示すものである。なお図中の小さいプ ロット点は, 図に示したそれぞれの条件で電解研削する場合の 過渡研削状態における $\dot{R}_{\mathrm{g}}$ と研削背分力 $p(t)$ の変化過程を示卞。 電解作用が弱まり $\left(\dot{R}_{\mathrm{g}}\right)_{\mathrm{s}}$ が大きくなるに従って定常研削背分力 $p_{\mathrm{s}}$ は大きくなる傾向にあるが， $\left(\dot{R}_{\mathrm{g}}\right)_{\mathrm{s}}$ が約 $0.2 \mu \mathrm{m} / \mathrm{rev}$ 以下になる 電解研削状態の $\left(\dot{R}_{\mathrm{g}}\right)_{\mathrm{s}}$ と $p_{\mathrm{s}}$ との関倸は， $\left(\dot{R}_{\mathrm{g}}\right)_{\mathrm{s}}$ が大きい状態にお ける両者の関係の延長線上にはなく, $\left(\dot{R}_{\mathrm{g}}\right)_{\mathrm{s}}$ の減少とともに $p_{\mathrm{s}}$ は かなり小さくなる傾向にあり， $\left(\dot{R}_{\mathrm{g}}\right)_{\mathrm{s}}$ が䄪 $0.2 \mu \mathrm{m} / \mathrm{rev}$ になる $C_{\mathrm{e}}=10 \%, E=10 \mathrm{~V}$ を境界として材料除去特性が大きく異なる. また，過渡研削過程における $\dot{R}_{\mathrm{g}} に$ 対する $p(t)$ の関係は，おおむ 权定常状態における両者の関係に沿って变化するが,定常研削 状態で $\left(\dot{R}_{\mathrm{g}}\right)_{\mathrm{s}}$ が $0.2 \mu \mathrm{m} / \mathrm{rev}$ より大きくなる $C_{\mathrm{e}}=6 \%, E=5,7.5 \mathrm{~V}$ の 場合では，電解研削初期の $\dot{R}_{\mathrm{g}}$ が小さい状態では $p(t)$ はそ机ほど 小さくならない，すなわち，定常研削状態において $\left(\dot{R}_{\mathrm{g}}\right)_{\mathrm{s}}$ 名約 $0.2 \mu \mathrm{m} / \mathrm{rev}$ 以下寸なわち $(\dot{R})_{s}$ が拈よそ $0.3 \mu \mathrm{m} / \mathrm{rev}$ 以上になる条 件では砥石に作用する負荷が急激に軽減される。このことは図 4 に示した加工面の光沢度の变化にも現机ており，( $\left.\dot{R}_{\mathrm{g}}\right)_{\mathrm{s}}$ が境界 である約 $0.2 \mu \mathrm{m} / \mathrm{rev}$ になる条件すなわち $\mathrm{C}_{\mathrm{e}}=10 \%, E=10 \mathrm{~V}$ を境 として，そ机より電解作用が一層強まる条件では光沢度は大き くなる.

\section{6. 加工動力から考慮した材料除去特性}

電解研削では,電解作用と砥粒切れ刃による研削作用の重冨 によって材料除去がなされる。したがって，材料除去能力を総 合的に検討するには電解作用も含めた加工動力を考虑する必要 がある。

図 13 は，定常研削状態に拀ける砥石と工作物間の電流加ら 求めた電力と研削動力の和である総消費動力 $U_{\mathrm{s}}$ に及ほす電解 条件の影響を示寸ものである。また図 14 は, 電解溶出電流か ら求めた電解電力と研削動力との和, すなわち切りくずによる 短絡などのため電解に要されない電力を総消費動力 Us いた有効動力U $\mathrm{e}$ 棇消費動力に占める割合 $U_{\mathrm{e}} / U_{\mathrm{s}}$ について電解 条件による影響を示すものである。総消費動力は電解液濃度お よび印加電压が大きくなるに従っておおむね滅少する傾向にあ る.このことは, 電解液㳻度拉よび印加電圧が大きくなること

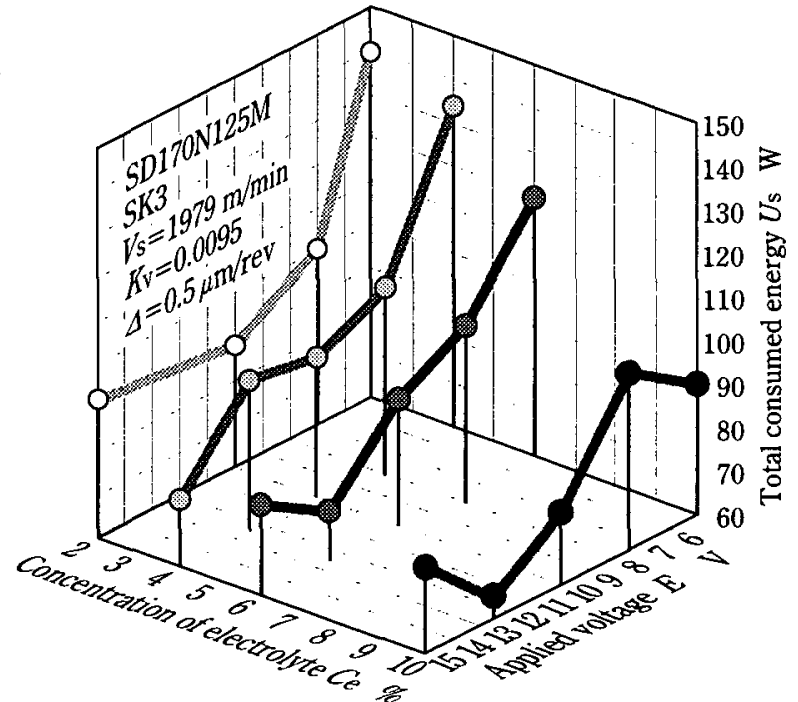

Fig. 13 Effects of concentration of electrolyte and applied voltage on total consumed energy in electrolytic grinding

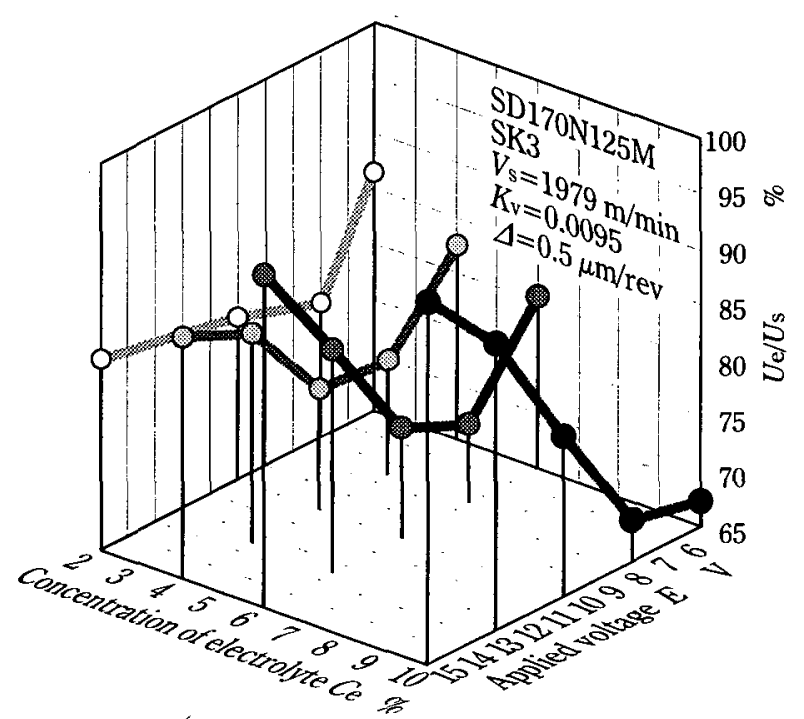

Fig. 14 Effects of concentration of electrolyte and applied voltage on effective energy ratio in electrolytic grinding

によって電解作用が強まり研削抵抗が減少する結果である.し かし, 総消費動力に占める有効動力の割合 $U_{\mathrm{e}} / U_{\mathrm{s}}$ は印加電圧が $7 \mathrm{~V}$ 程度で最も小さくなる，才なわち，充分大きな電解効果が 得られない条件では，切りくずを介した結合剤表面との短絡あ るいは放電によって必要以上に電力が消耗され，材料除去効率 の低下をもたらすことがわかる。したがって，U $U_{\mathrm{e}} / U_{\mathrm{s}}$ が小さい 電解条件では材料除去に要する動力はこれまで評価の对象とさ れてきた消費動力9" よりもかなり小さくなる．以上のことか ら,比較的低い電解液濃度あるいは比較的小さい印加電圧でそ れほど大きな電解作用が生じない場合は, 供給電力が材料除去 に有効に変換されない。

\section{7. 結 言}

円筒プランジ電解研削過程における材料除去現象を電解作用 および研削作用の钼点から検討し,電解条件による材料除去特 性の変化を明らかにした。本報で得られた主な結果は以下のと おりである。

(1) 電解液濃度ならびに印加電圧が比較的低い条件で電解研削 する場合は電解作用が小さいため，生成される切りくずを介 
した結合剤表面と工作物との瞬時の短絡などによって電流は 電解研削の進行とともに大幅に上昇し, 定常研削状態では電 解液濃度および印加電圧が大きい場合と同程度になる。

（2）砥石のかつぎ現象を考慮し,電解研削過程において砥石と 工作物間に流れる電流から工作物の電解溶出に要される電流 を抽出した。その電解溶出電流は砥石と工作物間で測定され る電流を下回り,電解液濃度および印加電圧が小さいほど両 者の差は大きい.

（3）電解液濃度および印加電圧が大きくなると電解作用が一層 強まる境界条件が存在し，そ机より高い電解作用が生じる条 件では，比研削抵抗が一段と小さくなり，砥石への負荷がか なり軽減される。

(4) 電解研削に要する総動力は電解液濃度および印加電珐が大 きくなるに従って小さくなるが，印加電圧がてV程度では電 解に要されない電流が增加し，動力損失が大きくなる。した がって,加工動力の観点からは大きな電解作用を誘発する条 件で電解研削することが有効である.
は小さくなり加工面の光沢度は減少するが, 更に電解作用が 強まると加工面粗さは更に改善されるものの光沢度は一転し て向上する.

$$
\text { 参考 文 献 }
$$

1）小野浩二, 島宗 勉, 山本辉久：電解研削に関する研究（第 1 報） 一電解平面研削機構について，精密機械，45，3（1979） 322.

2）小野浩二, 島宗 勉, 餅田正秋, 平山 忍：電解研削に関する研究 (第 2 報)一適正加工条件の選定，精密機械，48，3 (1982) 354.

3）長谷川嘉雄，花崎伸作，趾 睦，山本立春：高送り電解研削に関 する研究，精密工学会誌，52，7 (1986) 1236.

4）岡村健二郎, 中島利勝：研削の過渡特性 (第 1 報)一かつき現象の 解明, 精密機械, 38，7 (1972) 580.

5）東江真一，海野邦昭，筱崎 翼：ダイヤモンドホイールのドレッシ ングに関する研究一絴形ロータリドレッサの試作，昭和 62 年度精 密工学会春季大会学術講演会論文集（1987） 925 .

6）研削点に研削油剤を供給させる巻付けノスル，機械技術，40，9 (1992) 66.

7）日本規格協会：镜面光沢度一測定方法 JIS Z 8741 （1997） 1.

8）高橋正雄，增子 昇：工業電解の化学，アグネ (1979) 15.

9) 久保田 護：難削材料の電解放電研削, 精密機械, 50, 3 (1984) 520 .

（5）（3）の境界条件まで電解作用が強まるに従って加工面粗さ 